\title{
Transformational Leadership and Organizational Innovation: The Roles of Internal and External Support for Innovation*
}

\author{
Lale Gumusluoğlu and Arzu Ilsev
}

Leadership has been suggested to be an important factor affecting innovation. A number of studies have shown that transformational leadership positively influences organizational innovation. However, there is a lack of studies examining the contextual conditions under which this effect occurs or is augmented. Therefore, this study aimed to investigate the impact of transformational leadership on organizational innovation and to determine whether internal and external support for innovation as contextual conditions influence this effect. Organizational innovation was conceptualized as the tendency of the organization to develop new or improved products or services and its success in bringing those products or services to the market. Transformational leadership was hypothesized to have a positive influence on organizational innovation. Furthermore, this effect was proposed to be moderated by internal support for innovation, which refers to an innovation supporting climate and adequate resources allocated to innovation. Support received from external organizations for the purposes of knowledge and resource acquisition was also proposed to moderate the relationship between transformational leadership and organizational innovation. To test these hypotheses, data were collected from 163 research and development ( $R \& D$ ) employees and managers of 43 micro- and smallsized Turkish entrepreneurial software development companies. Two separate questionnaires were used to collect the data. Employees' questionnaires included measures of transformational leadership and internal support for innovation, whereas managers' questionnaires included questions about product innovations of their companies and the degree of support they received from external institutions. Organizational innovation was measured with a market-oriented criterion developed specifically for developing countries and newly developing industries. Hierarchical regression analysis was used to test the hypothesized effects. The results of the analysis provided support for the positive influence of transformational leadership on organizational innovation. This finding is significant because this positive effect was identified in micro- and small-sized companies, whereas previous research focused mainly on large companies. In addition, external support for innovation was found to significantly moderate this effect. Specifically, the relationship between transformational leadership and organizational innovation was stronger when external support was at high levels than when there was no external support. This study is the first to investigate and empirically show the importance of this contextual condition for organizational innovation. The moderating effect of internal

Address correspondence to: Lale Gumusluoğlu, Bilkent University, Department of Management, Bilkent, Ankara, Turkey. Tel.: + 90 (312) 2902319. Fax: +90 (312) 266-4958. E-mail: tomruk@ bilkent.edu.tr.

* An earlier version of this paper was published in the Proceedings, Portland International Conference on Management of Engineering and Technology (PICMET), eds. D. F. Kocaoglu et. al., pp. 898-907, July 8-13, 2006. 
support for innovation, however, was not significant. This study shows that transformational leadership is an important determinant of organizational innovation and encourages managers to engage in transformational leadership behaviors to promote organizational innovation. In line with this, transformational leadership, which is heavily suggested to be a subject of management training and development in developed countries, should also be incorporated into such programs in developing countries. Moreover, this study highlights the importance of external support in the organizational innovation process. The results suggest that technical and financial support received from outside the organization can be a more important contextual influence in boosting up innovation than an innovation-supporting internal climate. Therefore, managers, particularly of micro- and small-sized companies, should play external roles such as boundary spanning and should build relationships with external institutions that provide technical and financial support. The findings of this study are especially important for managers of companies that plan to or currently operate in countries with developing economies.

\section{Introduction}

A

lmost all organizations today are faced with a dynamic environment characterized by rapid technological change, shortening product life cycles, and globalization. It is apparent that organizations, especially technology-driven ones, operating in this kind of a market environment need to be more creative and innovative to survive, to compete, to grow, and to lead. Innovation through creativity is essential for the success and competitive advantage of organizations as well as for strong economies in the 21 st century. Hence, an increasing premium is placed on creativity and innovation in today's world (Mumford and Gustafson, 1988). This is why a growing number of practitioners and scholars have been attracted to this topic in recent decades.

\section{BIOGRAPHICAL SKETCHES}

Dr. Lale Gumusluoğlu is an instructor at Bilkent University. She received her Ph.D. in business administration from Hacettepe University. She is currently teaching international business, business strategy, and entrepreneurship and innovation management courses. Her research interests are entrepreneurship, creativity and innovation management, and leadership. She is a member of the executive board of Anatolian Strategic Research Foundation and Technology Management Foundation.

Dr. Arzu Ilsev is an instructor at Hacettepe University. She received her Ph.D. in business administration from the University of South Carolina. She is currently teaching organizational behavior, organizational development and change, research methods, and introduction to business courses Her research interests include leadership, supervisor-subordinate relationships, interpersonal processes at work, and cross-cultural organizational behavior.
Innovation is defined as the successful implementation of creative ideas within an organization (Amabile, 1983, 1998; Amabile et al., 1996). It has been suggested that leadership is among the most important factors affecting innovation (Cummings and O'Connell, 1978). This might be through leaders' effect on organizational characteristics such as culture, strategy, structure, reward systems, or resources (Woodman, Sawyer, and Griffin, 1993) or through a direct effect of their behavior on employees' creativity (Oldham and Cummings, 1996) and motivation (Tierney, Farmer, and Graen, 1999). Leaders can help their followers to exhibit higher levels of creativity at work (Shin and Zhou, 2003), can establish a work environment supportive of creativity (Amabile et al., 1996, 2004), can create an organizational climate serving as a guiding principle for more creative work processes (Scott and Bruce, 1994), and can develop and maintain a system that rewards creative performance through compensation and other human resource-related policies (Jung, Chow, and Wu, 2003). Furthermore, leaders can have an impact not only on innovation within the firm but also on marketing the innovative products. For example, their active participation in selling the innovative products might decrease resistance from the potential customers (Ettlie, 1983).

Recently, there has been an interest in the influence of transformational leadership on innovation. Transformational leaders are those leaders who transform followers' personal values and self-concepts, move them to higher levels of needs and aspirations (Jung, 2001), and raise the performance expectations of their followers (Bass, 1995). This leadership has four components: charismatic role modeling, individualized 
consideration, inspirational motivation, and intellectual stimulation. Using charisma, the leader instills admiration, respect, and loyalty and emphasizes the importance of having a collective sense of mission. By individualized consideration, the leader builds a one-to-one relationship with his or her followers and understands and considers their differing needs, skills, and aspirations. Thus, transformational leaders meet the emotional needs of each employee (Bass, 1990). By inspirational motivation, the leader articulates an exciting vision of the future, shows the followers the ways to achieve the goals, and expresses his or her belief that they can do it. By intellectual stimulation, the leader broadens and elevates the interests of his or her employees (Bass, 1990) and stimulates followers to think about old problems in new ways (Bass, 1985).

A number of studies have shown that transformational leadership positively influences organizational innovation (e.g., Jung et al., 2003). However, there is a lack of studies examining the contextual conditions under which this effect occurs or is augmented. Woodman et al. (1993) incorporated contextual factors in their interactionist approach to explain organizational creativity and suggested that external and intraorganizational influences have an impact on organizational innovation. Although relationships built with the external environment for the purposes of knowledge acquisition (Woodman et al., 1993) and resource acquisition (Cohen and Levinthal, 1990; Damanpour, 1991) have been theoretically suggested to be an important source of organizational innovation, empirical studies have not examined the moderating role of this contextual factor while investigating the relationship between transformational leadership and innovation. In addition to external support for innovation, support within the organization, in terms of an innovation supporting climate and adequate resources allocated to innovation, might also be an important contextual factor that plays a role in this relationship.

Thus, this study aims to examine the impact of transformational leadership on organizational innovation and the role played by internal and external support for innovation as contextual factors. A model of transformational leadership that includes these effects on organizational innovation was developed for this purpose. The model is depicted in Figure 1.

The model was tested on employees and managers of micro- and small-sized Turkish information technology (IT) companies engaged in software development. This study differs from most research in this area in three ways: It investigates transformational

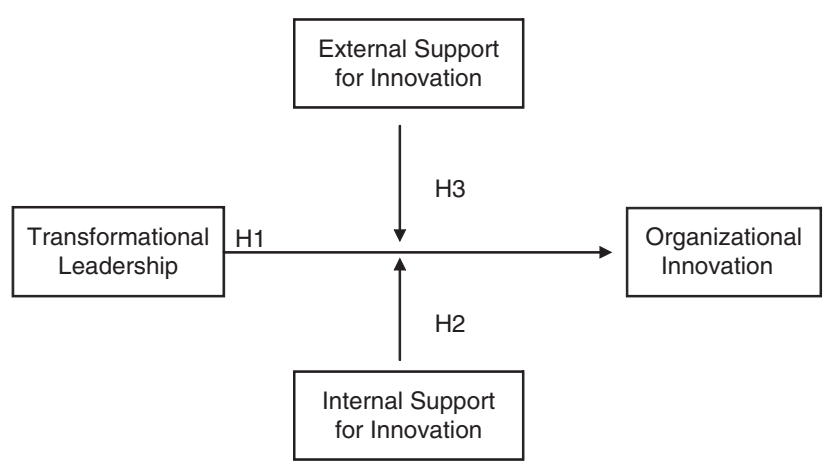

Figure 1. The Proposed Model

leadership and innovation (1) in a developing country, (2) in a newly developing industry in that country, and in (3) micro- and small-sized companies. Moreover, since creativity and innovation theories have been developed and tested mostly in Western countries, "research identifying what contextual conditions would be most relevant to individuals in different cultures is warranted" (Shalley, Zhou, and Oldham, 2004, p. 948).

\section{Theoretical Background and Hypotheses}

\section{Transformational Leadership and Organizational Innovation}

Woodman et al. (1993) define organizational innovation as the creation of valuable and useful new products/services within an organizational context. Since most organizations engage in innovative activity as a competitive weapon, the present study adopts a market-oriented approach and enhances this definition to include the returns due to innovation. Accordingly, organizational innovation in this study is defined as the tendency of the organization to develop new or improved products/services and its success in bringing those products/services to the market. This approach is consistent with Damanpour's (1991, p. 56) definition of product innovations as "new products/services introduced to meet an external user or market need" and the description provided by $\operatorname{OECD}(2004$, p. 64) as "the successful bringing of the new product or service to the market."

Transformational leaders have been suggested to have an impact on innovation. Transformational leaders enhance innovation within the organizational context - in other words, the tendency of organizations to innovate. Transformational leaders use inspirational motivation and intellectual stimulation, 
which are critical for organizational innovation (Elkins and Keller, 2003). Transformational leaders promote creative ideas within their organizations, and their behaviors are suggested to act as "creativity-enhancing forces"; individualized consideration "serves as a reward" for the followers, intellectual stimulation "enhances exploratory thinking," and inspirational motivation "provides encouragement into the idea generation process" (Sosik, Kahai, and Avolio, 1998, p. 113). Howell and Higgins (1990) state that this behavior reflects the "championing role" of the transformational leaders. This leader develops his or her followers' selfconfidence, self-efficacy, and self-esteem (Bass, 1990). Furthermore, this leader motivates his or her followers by his or her vision, increases their willingness to perform beyond expectations, and challenges them to adopt innovative approaches in their work. The resulting heightened levels of motivation and self-esteem in the followers are likely to enhance organizational innovation (Mumford et al., 2002).

Such a leader's positive impact on innovation was supported by a number of empirical studies (e.g., Keller, 1992; Waldman and Atwater, 1994). These studies focused on innovation mostly in research and development (R\&D) units and at the project level. The proposed effect of transformational leadership on innovation at the organizational level has become a topic of empirical research only recently. For example, Jung et al. (2003) found that transformational leadership was significantly and positively related to organizational innovation as measured by $R \& D$ expenditures and number of patents obtained over the previous three years.

In addition to its effect on the tendency of organizations to innovate, transformational leadership may also have a positive impact on the market success of the innovations. The transformational leader may mobilize his or her followers to ensure the innovations' success (Jung et al., 2003). By articulating a strong vision of innovation and displaying a sense of power and confidence, this leader will strive for ensuring the market success of the innovation. As Keller (1992) suggests, leading professional employees might require more than traditional leader behaviors especially in R\&D settings where quality rather than quantity is the primary performance criteria. Furthermore, in addition to the internal roles, transformational leadership has been suggested to be effective in playing external roles such as boundary spanning and entrepreneuring/championing (Howell and Higgins, 1990), which might be important both for understand- ing the needs of the market and marketing of the innovation successfully. Based on this, a positive impact of transformational leadership is expected on organizational innovation, which is conceptualized in this paper as including both the tendency of the organization to innovate and the success of innovations in the market.

H1: Transformational leadership is positively associated with organizational innovation.

\section{Internal Support for Innovation}

Organizations may internally support innovation by encouraging, recognizing, and rewarding creativity as well as by providing adequate amounts of such resources as personnel, funding, and time (Cohen and Levinthal, 1990; Scott and Bruce, 1994; Woodman et al., 1993). According to Amabile et al. (1996), employees' perceptions of such internal support in their work environment make up the psychological context of creativity, which in turn can influence their creative work. Similarly, Scott and Bruce (1994, p. 582) state that "climate represents signals individuals receive concerning organizational expectations for behavior and potential outcomes of behavior." That is, employees' perceptions of the extent to which creativity is encouraged at the workplace and the extent to which organizational resources are allocated to supporting creativity are likely to influence their innovative behavior. In line with this, when they perceive their organization as open to change and supportive of creative ideas and that there is an adequate supply of such resources as time, personnel, and funding, they are more likely to perceive the organizational climate as being supportive of innovation and hence to take risks and champion innovation. The positive direct effect of such perceptions on innovation has been empirically shown by a number of studies. For example, Abbey and Dickson (1983) showed that innovation in the R\&D units of 42 semiconductor companies was related to employees' perceptions of work climate, specifically of the extent to which rewards were tied to performance and the willingness of the organization to experiment with innovative ideas. Similarly, Scott and Bruce (1994) tested their model of individual innovative behavior on 172 employees of the R\&D facility of a major U.S. corporation and found that perceived support for innovation was positively associated with innovative behavior. 
Despite the theoretical propositions in favor of the climate's direct effect on innovation, several other studies reported inconsistent findings. For example, in a recent study conducted in a sample of 110 manufacturing firms in China, Wei and Morgan (2004) could not identify a direct relationship between supportiveness of climate and new product performance. Furthermore, support for innovation climate received only limited support as a mediator in the study by Scott and Bruce (1994, p. 602), where the researchers stated that "the role of climate as a mediator may be overstated in the literature, at least as it relates to innovative behavior."

Given these inconsistencies, it is interesting that there is a lack of studies evaluating the moderating role of this factor as representing more of a context within which the leader and his or her followers operate. Perhaps, supportive internal climate is not seen by the members of an organization as a direct force personally but rather as an organization-wide contextual factor that interacts with other innovation supporting factors to influence organizational innovation. In their interactionist model of organizational creativity, Woodman et al. (1993) explain organizational creativity as a function of the creative outputs of its component groups and contextual influences. In their approach, contextual influences are explained as enhancers and constraints on the creative accomplishments of individuals and groups and include organizational culture and climate as well as external environmental factors. Subsequently, in the present study, supportiveness of internal climate is expected to moderate the transformational leadership-organizational innovation relationship.

It was suggested that transformational leaders promote higher performance in organizational units that are open to change and flexible - in other words, in an innovative climate (Bass, 1985). Subsequently, Howell and Avolio (1993) found that the level of support for innovation climate moderated the relationship between transformational leadership and consolidated business unit performance of 78 managers in a Canadian financial institution. The degree of innovativeness in the work climate is expected in this study to become an even more crucial contextual factor when the measure of performance under investigation is specifically creativity and innovation. Such internal support might strengthen the influence of transformational leadership on innovation for at least two reasons. The first is that when employees perceive an innovative climate, they will be encouraged to take initiative and risks and will be challenged to seek innovative approaches in their work. Second, they might respond better to transformational leadership when they perceive that they are provided with adequate resources and support. In other words, within such a supportive context the effect of transformational leadership on innovation will be stronger. Therefore,

\section{H2: Internal support for innovation moderates the relationship between transformational leadership and organizational innovation such that the effect of this leadership on organizational innovation will be stronger when internal support for innovation is higher.}

\section{External Support for Innovation}

One important source of organizational innovation is the knowledge acquired from the firm's external environment. Woodman et al. (1993) hypothesized that information exchanges with the environment are an important contextual variable affecting organizational innovation. Damanpour (1991), in his meta-analytical review of the organizational innovation studies, reported a positive association between external communication and innovation. Cohen and Levinthal (1990, p. 139) suggested that "external knowledge might complement and leverage a firm's own knowledge output" and thus be a critical source of organizational innovation.

Resource availability is another important factor in organizational innovation (Cohen and Levinthal, 1990; Damanpour, 1991). The amount of resources such as personnel and funding affect the followers' perceptions of an environment supportive of innovation in their organizations (Amabile et al., 1996; Scott and Bruce, 1994). Furthermore, Woodman et al. (1993) maintain that availability of slack resources enhances organizational creative performance. Therefore, resources obtained from outside the organization can be crucial for organizational innovation.

For the reasons previously stated, firms can build a wide range of relationships with different parties. They can build strategic alliances with other companies for sharing expertise, funding, or output; they can cooperate with research institutes and universities for technical assistance and consulting; and they can receive financial and technical help from public or private support organizations for innovative projects.

Based on previous research, receiving either knowledge-based or resource-based support (i.e., technical and financial assistance) from external institutions is proposed in this study to interact with other innova- 
tion-supporting factors. This might be especially important for firms that lack sufficient internal resources. Consequently, it is proposed here that the positive impact of transformational leadership on organizational innovation depends on the degree of external support. It is expected that, under a higher level of technical and financial assistance acquired from outside the firm, the transformational leader will find more support for his or her vision, and, thereby, his or her effect on organizational innovation will be stronger.

H3: External support moderates the relationship between transformational leadership and organizational innovation such that the effect of transformational leadership on organizational innovation will be stronger when the degree of external support is higher.

\section{Methods}

\section{Sample}

Employees and their leaders in 43 Turkish entrepreneurial software development companies participated in this study. The sample was a highly homogeneous one in terms of size and type of task. All companies were micro- and small-sized with 3 to 17 employees, and all were engaged in the development of new products and the improvement of existing products described as development work by Keller (1992).

A total of 163 employees participated in the current study. There were 130 men $(79.7 \%)$ and 33 women $(20.3 \%)$ in the sample. The average age of the followers was 27.6 years; $4.3 \%$ had high school diplomas, $71.2 \%$ had bachelor's degrees, $22.1 \%$ had master's degrees, and $2.5 \%$ had Ph.D.s. The employees had 2.25 years of average company tenure and 4.71 years of average job tenure in the sector. All participants were Turkish. The average age of the companies was 5.9 years, and the average size was 9.4 employees.

Micro- and small-sized entrepreneurial companies were chosen rather than large ones because they may be more innovative due to their "greater flexibility" and they may have "younger and more growth-oriented personnel" (Ettlie, 1983, p. 29). Moreover, entrepreneurship orientation has been suggested (Kitchell, 1995) and empirically found (Salavou and Lioukas, 2003) to be a driver of innovation. Practical observations support these theoretical arguments. According to the Technological Innovation Activities Survey (DIE, 2004), in the service sector, the share of innovativeness is $35.4 \%$ in micro-sized firms (1-9 employees), $24 \%$ in firms with 10-19 employees, and $16.7 \%$ in firms with $20-49$ employees. Hence, the firms in the present sample, with an average of 9.4 employees, were appropriate for the measurement of innovation.

Studying the software development industry is important for two reasons. First, this industry has an increasing share of the industrial innovations in the world (OECD, 1996). Second, this sector's higher level of innovativeness compared with other sectors in Turkey makes it a good area in which to measure this quality. According to the Technological Innovation Activities Survey conducted by the Turkish State Institute of Statistics for 1998-2000, in the IT sector, the share of innovativeness is about $50 \%$ and the share of $R \& D$ in total innovation expenditures is higher than that of the other sectors (DIE, 2004). Furthermore, the development tasks that software companies work on do require creativity (Couger, Higgins, and McIntyre, 1993) as they produce incremental innovations (Elkins and Keller, 2003). However, this industry has been neglected by empirical researchers in spite of its significance.

\section{Procedure}

Interviews were conducted with six company owners in the software development industry to understand the specific nature of the development work in which the companies were engaged. In addition, the definition of innovation and the specific descriptions of a technologically new product and an improved product adopted in this study were explained. They unanonimously agreed that the statements reflected the development work in which they were engaged. Participants were also provided with the measures of organizational innovation commonly used in empirical research (e.g., number of patents and R\&D intensity) and were asked to recommend measures for their industry. These comments and recommendations were taken into consideration while developing the measure of organizational innovation by the authors and then were presented to the leaders. The participants agreed with the measure without exception.

The participant companies of this study were identified in two stages. In the first stage, personal contact was established with the managers of three technoparks located in three respected Turkish universitiesBilkent University, Middle East Technical University, and Hacettepe University. Out of a total of 325 firms in these technoparks, the managers identified 90 com- 
panies that were micro and small sized and were part of the software development industry. The reasons for these two criteria were explained in the previous sample section. In the second stage, managers of these 90 companies were contacted by phone and asked whether they satisfied the other two criteria of this study, which were in particular determined for measurement purposes: minimum firm age of three years and in-house software development. Of the 49 who met these criteria, 43 agreed to participate in the study. The leaders of these companies were both the owner-managers and immediate supervisors of the R\&D personnel. They provided the names of the $R \& D$ employees engaged in the problem definition and design stages of software development.

Data were collected by two separate questionnaires: one for the employees and the other for their leaders. Data collected from the leaders and employees were matched and grouped for analysis. Out of 168 employees, 5 did not complete the questionnaire. All of the questionnaires were completed during regular working hours, and the authors were present to answer questions and to collect completed surveys. Since all of the participants in this study were Turkish, all questionnaire items (except the Multi-Factor Leadership Questionnaire [MLQ], for which the copyright had been obtained for the Turkish version) were carefully translated and back-translated to ensure conceptual equivalence and comparability (Brislin, 1986).

Employees' questionnaires included measures of transformational leadership and internal support for innovation. On average, four employees rated each leader. Employees were also asked for their age, gender, educational level, job tenure, and company tenure. Leaders' questionnaires included questions about company age, company innovations, and the degree of support they received from external institutions.

\section{Measures}

Transformational Leadership. Transformational leadership was measured using 20 items from the Turkish version of the MLQ (Form 5X) (Bass and Avolio, 1995). Avolio, Bass, and Jung (1999) provided support for the convergent and discriminant validity of the instrument. If subordinates provided both the transformational leadership ratings and the criterion ratings, the results could have been potentially biased by samesource (MLQ) data. Therefore, only the transformational leadership items were used. Participants were asked to judge how frequently their immediate leader engaged in transformational leadership behaviors. Ratings were completed on a five-point scale with 1 representing "Not at all" and 5 representing "Frequently, if not always." Sample items included "Articulates a compelling vision of the future," "Treats me as an individual rather than as a member of the group," and "Gets me to look at problems from many different angles."

Exploratory factor analysis using the principal components method and varimax rotation was conducted on the 20 items to determine their factor structure. After two items with factor loadings less than 0.50 were removed, the resulting 18 items loaded on one factor, which accounted for $47.06 \%$ of the variance. Thus, these items were averaged to form a scale. Reliability (i.e., Cronbach's alpha) of the scale was 0.93. Bycio, Hackett, and Allen (1995) showed that the dimensions of transformational leadership failed to exhibit discriminant validity in predicting outcomes. Furthermore, since there was not any a priori expectation that individual dimensions of transformational leadership would differentially affect creativity, a single index was used to measure transformational leadership. The use of a single scale to represent transformational leadership has been validated by prior research (Judge and Bono, 2000).

Internal Support for Innovation. This variable was measured by 12 items adapted from Scott and Bruce's (1994) measure of perception of support for innovation climate. On a five-point scale ranging from 1 ("Strongly disagree") to 5 ("Strongly agree"), employees indicated the extent to which their companies supported innovation. Sample items were "This organization can be described as flexible and continually adapting to change" and "There are adequate resources devoted to innovation in this organization." Based on the factor analysis results, three items with loadings less than 0.50 were removed. The remaining nine items loaded on one factor that accounted for $55.40 \%$ of the variance. These items were averaged to form a scale with a reliability of 0.88 .

Aggregation of Transformational Leadership and Internal Support for Innovation Ratings. Since the dependent variable of this part of the analysis is organizational innovation, transformational leadership ratings as well as perceptions of internal support for innovation by the subordinates needed to be aggregated to organizational level. These variables were aggregated by averaging their values for each organiza- 
tion. Empirical justification for aggregating both of these subordinate ratings was obtained using one-way analysis of variance (ANOVA). The results for transformational leadership showed that between-group differences were significantly higher than within-group differences $(F=3.06, p<.001)$. Similarly, between-group differences in perceptions of internal support for innovation were significantly higher than within-group differences $(F=2.83, p<.001)$. Interrater reliabilities of subordinate ratings of transformational leadership (intraclass correlation coefficient $[\mathrm{ICC}] 1=0.52, \mathrm{ICC} 2=0.67)$ and internal support $(\mathrm{ICC} 1=0.50, \mathrm{ICC} 2=0.65)$ were also at acceptable levels. These results showed that aggregation was appropriate for these variables.

External Support for Innovation. To measure this variable, leaders were asked to indicate how many of their innovative projects received resource-based and knowledge-based support (i.e., financial and technical assistance) from external institutions in the last three years. The external institutions were organizations that support innovative projects, namely TUBITAK-TIDEB (Scientific and Technical Research Council of Turkey-Technology Monitoring and Evaluation Board) and TTGV (Technology Development Foundation of Turkey) (described in the Appendix). The definition of innovation and the descriptions of development and improvement work adopted by these institutions were the same as those of this study.

Organizational Innovation. Organizational innovation is defined in this study as the tendency of the organization to develop new or improved products/ services and its success in bringing that product/ service to the market. Consistent with this definition and taking into consideration the comments of the leaders made during the interview, a new criterion for measuring organizational innovation was developed. The leaders' common concern was that such quantifiable measures as copyrights or quality certificates, which are commonly employed to study established companies in developed industries and countries, might not be applicable to small-sized entrepreneurial companies in Turkey due to the poorly established rules of competition and legal structure in the country. Furthermore, the highly uncertain and dynamic nature of the software development industry (MacCormack and Verganti, 2003) demands that a company's ability to successfully market its innovations should also be measured. Therefore, a marketoriented approach was adopted in this study rather than quantifiable input measures for developing the measurement of organizational innovation.

The measure of organizational innovation in the study is the product of two ratios, namely, coefficient of innovativeness tendency and the success of product innovations. Coefficient of innovativeness tendency was measured as the ratio of sales generated by product innovations to total sales. This coefficient quantifies the innovativeness orientation of companies engaged in work other than software development such as marketing computer hardware. This measure of innovative activity was also used by Czarnitzki and Kraft (2004), who investigated the innovative performance of European firms. To operationalize the present study's definition of organizational innovation, this measure was employed as a coefficient to modify the success of product innovations.

Success of Product Innovations was computed as the sales generated by product innovations over expenditures in producing those product innovations. This ratio shows the success of the organization in both satisfying market needs and utilizing the organization's resources in producing the innovations. This is a better measure of outcomes than the R\&D expenditures measured in absolute numbers. As stated by Jung et al. (2003), expenditures for innovation itself do not reflect the success of the company in generating "outcomes" but rather its "willingness" to support innovation.

The definition of organizational innovation of the present study captures product innovations. Thus, to measure organizational innovation leaders were first asked to analyze every product of their company to determine whether it would be considered a product innovation. Innovation in this study is defined as an important product, process, or idea leading to a new or improved product that is new to the organization (Keller and Holland, 1983). In more specific terms, product innovations are defined as new products developed, existing products improved (ibid.), and custom-made projects (OECD, 1996) that display significantly different attributes from the firms' previous products. These definitions are specific and quantifiable and focus on product innovations compared with others that define innovation as "the successful implementation of creative ideas within an organization" (Amabile et al., 1996, p. 1155). These definitions along with descriptions of technological product innovations and examples of product innovations in the software development companies (OECD, 1996) were included in the questionnaire administered to the leaders (provided in the Appendix). 
After the leaders identified their product innovations in accordance with these definitions and descriptions, they were asked three questions: total sales generated by product innovations during the previous three years, total sales of the company during the previous three years, and total expenditures in producing those product innovations during the same time period. The three-year time frame was chosen to take into account the newly emerging nature of this market in Turkey where both software development and sales might take a longer time.

Control Variable. Firm age was used as a control variable in this part of the study, since prior studies reported its positive relationship with organization innovation (Hitt, Hoskisson, and Kim, 1997; Jung et al., 2003).

\section{Results}

\section{Descriptive Statistics}

Means, standard deviations, and correlations among organizational-level variables are presented in Table 1 . Transformational leadership had significant correlations with organizational innovation $(r=0.30, p<.05)$ and perceptions of support for innovation climate $(r=0.81$, $p<.001)$. Another significant correlation was between firm age and external support $(r=0.48, p<.01)$.

\section{Hypothesis Tests}

A four-stage hierarchical regression analysis was used to test the hypothesized direct effect of transformational leadership and the moderating effects of inter-

Table 1. Descriptive Statistics and Correlations among the Variables

\begin{tabular}{|c|c|c|c|c|c|c|}
\hline Variables & Mean & S.D. & 1 & 2 & 3 & 4 \\
\hline $\begin{array}{l}\text { 1. Transformational } \\
\text { Leadership }\end{array}$ & 3.90 & 0.53 & & & & \\
\hline $\begin{array}{l}\text { 2. Internal Support } \\
\text { for Innovation }\end{array}$ & 3.77 & 0.58 & $0.81^{* * *}$ & & & \\
\hline $\begin{array}{l}\text { 3. External Support } \\
\text { for Innovation }\end{array}$ & 0.51 & 1.32 & -0.06 & -0.19 & & \\
\hline 4. Firm Age & 5.90 & $3.73-$ & -0.11 & -0.12 & $0.48^{* *}$ & \\
\hline $\begin{array}{l}\text { 5. Organizational } \\
\text { Innovation }\end{array}$ & 1.57 & 0.56 & $0.30^{*}$ & 0.21 & 0.13 & 0.29 \\
\hline
\end{tabular}

nal and external support for innovation. In stage 1, the control variable (firm age) was entered as a predictor of innovation. Next, the main effects predictor variables (transformational leadership, internal support for innovation, and external support for innovation) were entered. In the third and fourth steps, the multiplicative interaction terms were entered separately. The moderator hypotheses were tested by examining the significance of the interaction terms and the $F$-tests associated with the changes in the multiple squared correlation coefficients $\left(R^{2}\right.$ 's) of the equations in the third and fourth steps. Following Aiken and West's (1991) recommendation for regression analysis with multiplicative interaction terms, all the variables in the regression equations were centered. Table 2 shows the results of this analysis.

$\mathrm{H} 1$ predicted a positive relationship between transformational leadership and organizational innovation. Results of the analysis revealed that, after controlling for firm age, transformational leadership had a significant positive effect on organizational innovation $(b=0.65, p<.05)$. Therefore, H1 was supported.

$\mathrm{H} 2$ was related to the moderating effect of internal support for innovation on the relationship between transformational leadership and organizational innovation. The results showed that the interaction between perceptions of internal support for innovation and transformational leadership was not significant $(b=-0.18, \mathrm{n} . \mathrm{s})$. Change in the $R^{2}$ when the interaction term was added was also not significant $\left(\Delta R^{2}=0.00\right.$, n.s.). Thus, $\mathrm{H} 2$ was not supported.

Table 2. Results of the Moderated Regression Analysis for Organizational Innovation

\begin{tabular}{lcrrc}
\hline & Step 1 & Step 2 & Step 3 & Step 4 \\
\hline Firm Age & 0.04 & 0.05 & 0.05 & 0.04 \\
Transformational Leadership & & 0.41 & 0.35 & $0.65^{*}$ \\
Internal Support for & & -0.06 & -0.06 & -0.16 \\
Innovation & & & & \\
External Support for & & & & 0.01 \\
Innovation & & & -0.18 & -0.05 \\
Transformational & & & & \\
$\quad$ Leadership $\times$ Internal & & & & $0.61^{*}$ \\
$\quad$ Support for Innovation & & & & \\
Transformational & 3.68 & 2.30 & 1.90 & $3.01^{*}$ \\
$\quad$ Leadership $\times$ External & 1 & 4 & 5 & 5 \\
$\quad$ Support for Innovation & 0.08 & 0.20 & 0.20 & 0.29 \\
$F$ & & 0.12 & 0.00 & $0.09^{*}$ \\
$D f$ & & & & \\
$R^{2}$ & & &
\end{tabular}




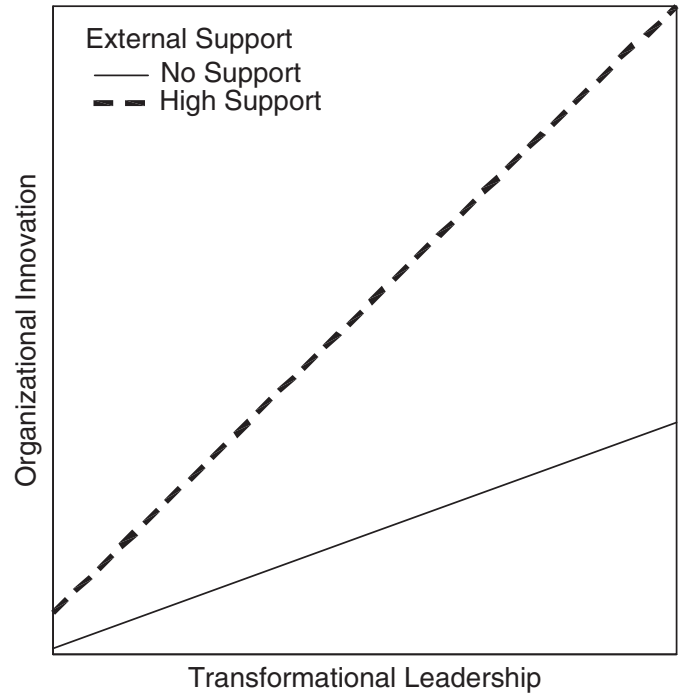

Figure 2. Moderating Effect of External Support for Innovation on the Transformational Leadership-Organizational Innovation Relationship

H3 predicted a moderating effect of external support on the relationship between transformational leadership and organizational innovation. According to the results, the interaction term was statistically significant $(b=0.61, p<.05)$. Change in the $R^{2}$ when the interaction term was added was also significant $\left(\Delta R^{2}=0.09, p<.05\right)$. Therefore, transformational leadership and external support had a significant joint effect on organizational innovation.

To interpret the form of the moderated relationship, the interaction effect was plotted using the procedure suggested by Aiken and West (1991). Specifically, the regression equations of transformational leadership on organizational innovation for high and low levels of the moderating variable external support were plotted. High levels of external support were defined as one standard deviation above its mean; for low levels 0 was used, since the minimum number of external support could only be zero. Figure 2 depicts the interaction plot.

As predicted by $\mathrm{H} 3$, the positive impact of transformational leadership on organizational innovation is stronger for higher levels of external support. Thus, H3 was supported.

\section{Discussion}

This study has theoretical contributions to the literature. First, in line with Jung et al. (2003), transformational leadership was found to have a significant positive influence on organizational innovation. Sec- ond, this study identified the significant positive effect of this leadership on organizational innovation for micro-and small-sized companies, whereas previous research focused mainly on large companies. Third, since the innovations under investigation in this study were related to developmental work, the positive influence of this leadership was demonstrated on incremental innovation. Although Keller (1992) suggests that developmental work might require more of a transactional leader than a transformational one, the results of this study show that transformational leadership is also important for the incremental innovation seen in developmental work. Furthermore, as stated before, previous research focused on this leader's effect on the tendency of organizations to innovate. The present study's definition of organizational innovation included the success of innovations as well as the tendency to innovate. Therefore, the findings of this study suggest that transformational leaders might not only promote innovative activity within the organization but also ensure the market success of the innovations.

These results also showed that external support moderated the relationship between transformational leadership and organizational innovation. It is suggested in the literature (Elkins and Keller, 2003) that relationships built with the external environment, in particular for the acquisition of knowledge and resources, play a significant role in the innovation process. Therefore, it is equally important to have shown empirically that this leader's effect on organizational innovation increases under a high level of such external support. This is especially important for micro- and small-sized enterprises that may not have adequate internal financial and technical resources for innovation. To the best of our knowledge, this is the first study investigating the effects of transformational leadership in this contextual condition.

Although not hypothesized in this study, an interesting finding was that external support does not have a direct influence on organizational innovation. This suggests that external support, by itself, is not enough to develop new products and services and to market them successfully. Rather, it serves as leverage for the effect of transformational leadership on innovation.

Interestingly, the hypothesized moderator role of internal support for innovation was not confirmed. This might be due to the sample in this study, which includes micro- and small-sized companies. Perhaps for such companies, external support may be more significant than internal support in facilitating orga- 
nizational innovation. Moreover, a supportive climate might be a more important contextual influence in producing radical rather than incremental innovations. Another reason for this finding might be that the high correlation between transformational leadership and perceptions of internal support for innovation might have diminished the contribution of perceptions of internal support in predicting organizational innovation, resulting in a nonsignificant relationship.

This study is not without its limitations. It focused on micro- and small-sized companies producing incremental innovation; therefore, the findings may not be generalizable to large companies and those producing radical innovations. Another limitation of the study was the cross-sectional design employed. In real work settings, longitudinal studies can better analyze the effects of internal support for innovation and future organizational innovations.

\section{Directions for Future Research}

This study investigated the direct and moderated relationships between transformational leadership and organizational innovation. Future research might also examine the processes that mediate this relationship. Furthermore, the external support found to be a significant moderator of the transformational leadership-organizational innovation relationship in this study focused on relationships with support institutions. Future studies could look at the effects of other contextual variables such as relationships with customers and competitors in the market. Moreover, studies should be conducted to examine whether external and internal support plays an important role in the innovation process in industries that produce radical innovation. In addition, it might also be interesting to investigate the conditional factors under which internal support influences innovation in small companies.

\section{Practical Implications}

This study shows that transformational leadership is an important determinant of organizational innovation. This suggests that managers should engage in transformational leadership behaviors in order to promote organizational innovation. Specifically, they should (1) build individualized relationships with employees and consider their needs, aspirations, and skills, (2) articulate an exciting vision of the future and inspire and motivate employees to work toward this vision, and (3) stimulate them intellectually by broadening their interests and encouraging them to think about old problems in new ways.

This study is the first to investigate transformational leadership and its effect on organizational innovation in a developing country and can extend our understanding of organizational innovation in countries that share similar structures, conditions, and institutions with Turkey. In most developing countries innovation is not a priority and is generally neglected by organizations. However, to be able to compete in the global arena successfully, organizations in such countries need to be innovative. Since this study showed transformational leadership to be an important determinant of organizational innovation, we recommend that transformational leadership, which is heavily suggested to be a subject of management training and development in developed countries, should also be incorporated into such programs in developing countries.

This study highlights the importance of external support in the organizational innovation process. The results implied that internal support for innovation by itself may not be sufficient to promote organizational innovation, in particular incremental innovations. Rather, it is the support received from outside the organization that serves as leverage to the effect of transformational leadership on organizational innovation. Therefore, to boost the level of company innovation, managers, especially of micro- and smallsized entrepreneurial companies, should play external roles such as boundary spanning and entrepreneuring/ championing and should build relationships with external institutions that provide technical and financial support.

Furthermore, policies that relate to such support should be developed and implemented in developing countries, which still lack both a shared vision and a commitment by stakeholders to establish a national innovation system. In developing countries, government financing of R\&D should be directed also to micro- and small-sized firms, not solely to large firms. In 2003, Turkish firms with fewer than 50 employees received only about $6 \%$ of government-financed business R\&D while their counterparts in Ireland, New Zealand, and Australia received more than 50\% (OECD, 2005). According to the American National Science Organization, small businesses are estimated to be $98 \%$ more successful than large ones in launching new products and services (Wheelen and Hunger, 
2000). Similarly, the U.S. Small Business Administration found that small firms produce more economically and technically important innovations than larger ones (Zimmerer and Scarborough, 2005). Thus, the high innovation potential of micro- and small-sized firms can be realized only with higher levels of support and commitment by all stakeholders.

In recent years, Turkey has started to attract an increasing amount of foreign direct investment because of its fast growing economy; it is a large undeveloped market opportunity to Western businesses. For managers of companies that plan to or currently operate in developing countries, this study provides insights into understanding organizational innovation in Turkey and in countries with similar developing economies. The findings of this study might be of interest to them as these findings might be different from results in the Western context. These managers should bear in mind that transformational leadership is important to increase the performance of employees in companies producing incremental innovation. In addition, technical and financial support received from outside the organization can be a more important contextual influence in boosting up innovation in especially micro- and small-sized companies of such than an innovation-supporting internal climate. While such external support can complement and strengthen the technical and financial resources of their company, it can also encourage employees in developing countries to be more energized and to exhibit their best performance. At the same time, this contextual influence provides support for the vision of transformational managers, thus enhancing the positive effects of such leaders on innovation within their companies.

\section{References}

Abbey, A. and Dickson, J.W. (1983). R\&D Work Climate and Innovation in Semiconductors. Academy of Management Journal 26(2):362-368.

Aiken, L.S. and West, S.G. (1991). Multiple Regression: Testing and Interpreting Interactions. Newbury Park, CA: Sage.

Amabile, T.M. (1983). The Social Psychology of Creativity. New York: Springer-Verlag.

Amabile, T.M. (1998). How to Kill Creativity. Harvard Business Review 76(5):77-87.

Amabile, T.M., Conti, R., Coon, H., Lazenby, J., and Herron, M. (1996). Assessing the Work Environment for Creativity. Academy of Management Journal 39(5):1154-1184.

Amabile, T.M., Schatzel, E.A., Moneta, G.B., and Kramer, S.J. (2004). Leader Behaviors and the Work Environment for Creativity: Perceived Leader Support. Leadership Quarterly 15(1):5-32.

Avolio, B.J., Bass, B.M., and Jung, D.I. (1999). Re-examining the Components of Transformational and Transactional Leadership
Using the Multifactor Leadership Questionnaire. Journal of Occupational and Organizational Psychology 72(4):441-463.

Bass, B.M. (1985). Leadership and Performance Beyond Expectations. New York: Free Press.

Bass, B.M. (1990). From Transactional to Transformational Leadership: Learning to Share the Vision. Organizational Dynamics 18(3):19-32.

Bass, B.M. (1995). Transformational Leadership. Journal of Management Inquiry 4(3):293-298.

Bass, B.M. and Avolio, B.J. (1995). MLQ: Multifactor Leadership Questionnaire, (2nd ed.). Redwood City, CA: Mind Garden.

Brislin, R. (1986). The Wording and Translation of Research Instruments. In: Field Methods in Cross-Cultural Research, ed. W.J. Lonner, and J.W. Berry. Beverly Hills, CA: Sage, 137-164.

Bycio, P., Hackett, R.D., and Allen, J.S. (1995). Further Assessment of Bass's (1985) Conceptualization of Transactional and Transformational Leadership. Journal of Applied Psychology 80:468-478.

Cohen, W.M. and Levinthal, D.A. (1990). Absorptive Capacity: A New Perspective on Learning and Innovation. Administrative Science Quarterly 35:128-152.

Couger, J.D., Higgins, L.F., and McIntyre, S.C. (1993). Unstructured Creativity in Information Systems Organizations. MIS Quarterly 17(4):375-397.

Cummings, L.L. and O'Connell, M.J. (1978). Organizational Innovation. Journal of Business Research 6:33-50.

Czarnitzki, D. and Kraft, K. (2004). Firm Leadership and Innovative Performance: Evidence from Seven EU Countries. Small Business Economics 22:325-332.

Damanpour, F. (1991). Organizational Innovation: A Meta-analysis of Effects of Determinants and Moderators. Academy of Management Journal 34:555-590.

DIE (State Institute of Statistics) (2004). Technological Innovation Activities Survey 1998-2000. Retrieved from http://www.die.gov.tr/ TURKISH/SONIST/TEKNYHZ/hizmetsek0104/page0005.html.

Elkins, T. and Keller, R.T. (2003). Leadership in Research and Development Organizations: A Literature Review and Conceptual Framework. Leadership Quarterly 14:587-606.

Ettlie, J.E. (1983). Organizational Policy and Innovation among Suppliers to Food Processing Sector. Academy of Management Journal 26(1):27-44.

Hitt, M.A., Hoskisson, R.E., and Kim, H. (1997). International Diversification: Effects on Innovation and Firm Performance in Product-Diversified Firms. Academy of Management Journal 40(4): 767-798.

Howell, J.M. and Avolio, B.J. (1993). Transformational Leadership, Transactional Leadership, Locus of Control, and Support for Innovation. Journal of Applied Psychology 78(6):891-902.

Howell, J.M. and Higgins, C.A. (1990). Champions of Technological Innovation. Administrative Science Quarterly 35:317-341.

Judge, T.A. and Bono, J.E. (2000). Five-Factor Model of Personality and Transformational Leadership. Journal of Applied Psychology $85: 751-765$.

Jung, D.I. (2001). Transformational and Transactional Leadership and Their Effects on Creativity in Groups. Creativity Research Journal 13(2):185-195.

Jung, D.I., Chow, C., and Wu, A. (2003). The Role of Transformational Leadership in Enhancing Organizational Innovation: Hypotheses and Some Preliminary Findings. Leadership Quarterly 14:525-544.

Keller, R.T. (1992). Transformational Leadership and The Performance of Research and Development Project Groups. Journal of Management 18(3):489-501.

Keller, R.T. and Holland, W.E. (1983). Communicators and Innovators in Research and Development Organizations. Academy of Management Journal 26(4):742-749. 
Kitchell, S. (1995). Corporate Culture, Environmental Adaptation, and Innovation Adoption: A Qualitative/Quantitative Approach. Journal of the Academy of Marketing Science 23(3): 195-205.

MacCormack, A. and Verganti, R. (2003). Managing the Sources of Uncertainty: Matching Process and Context in Software Development. Journal of Product Innovation Management 20:217-232.

Mumford, M.D. and Gustafson, S.B. (1988). Creativity Syndrome: Integration, Application, and Innovation. Psychological Bulletin 103(1):27-43.

Mumford, M.D., Scott, G.M., Gaddis, B., and Strange, J.M. (2002). Leading Creative People: Orchestrating Expertise and Relationships. Leadership Quarterly 13(6):705-750.

Organisation for Economic Co-operation and Development (OECD) (1996). The Measurement of Scientific and Technological Activities: Proposed Guidelines and Interpreting Technological Innovation Data (Oslo Manual). Retrieved from http://www.oecd.org/ dataoecd/35/61/2367580.pdf.

Organisation for Economic Co-operation and Development (OECD) (2004). Small and Medium-Sized Enterprises in Turkey: Issues and Policies. Paris: OECD.

Organisation for Economic Co-operation and Development (OECD) (2005). Science, Technology and Industry Scoreboard. Retrieved from http://www.oecd.org/sti/scoreboard.

Oldham, G.R. and Cummings, A. (1996). Employee Creativity: Personal and Contextual Factors at Work. Academy of Management Journal 39(3):607-634.

Salavou, H. and Lioukas, S. (2003). Radical Product Innovations in SMEs: The Dominance of Entrepreneurial Orientation. Creativity and Innovation Management 12(2):94-108.

Scott, S.G. and Bruce, R.A. (1994). Determinants of Innovative Behavior: A Path Model of Individual Innovation in the Workplace. Academy of Management Journal 37(3):580-607.
Shalley, C.E., Zhou, J., and Oldham, G.R. (2004). The Effects of Personal and Contextual Characteristics on Creativity: Where Should We Go from Here? Journal of Management 30(6): 933-958.

Shin, S.J. and Zhou, J. (2003). Transformational Leadership, Conservation and Creativity: Evidence from Korea. Academy of Management Journal 46(6):703-714.

Sosik, J.J., Kahai, S.S., and Avolio, B.J. (1998). Transformational Leadership and Dimensions of Creativity: Motivating Idea Generation in Computer-Mediated Groups. Creativity Research Journal 11(2):111-121.

Tierney, P., Farmer, S.M., and Graen, G.B. (1999). An Examination of Leadership and Employee Creativity: The Relevance of Traits and Relationships. Personnel Psychology 52: 591-620.

Waldman, D.A. and Atwater, L.E. (1994). The Nature of Effective Leadership and Championing Processes at Different Levels in an R\&D Hierarchy. Journal of High Technology Management Research 5(2):233-245.

Wei, Y. and Morgan, N.A. (2004). Supportiveness of Organizational Climate, Market Orientation, and New Product Performance in Chinese Firms. Journal of Product Innovation Management 21:375388.

Wheelen, T.L. and Hunger, J.D. (2000). Strategic Issues in Entrepreneurial Ventures and Small Businesses. In: Strategic Management: Year 2000, The New Global Millenium, ed. O.A. Shater. London: Prentice-Hall, 283-304.

Woodman, R.W., Sawyer, J.E., and Griffin, R.W. (1993). Toward a Theory of Organizational Creativity. Academy of Management Review 18(2):293-321.

Zimmerer, T.W. and Scarborough, N.M. (2005). Essentials of Entrepreneurship and Small Business Management. Upper Saddle River, NJ: Pearson Education.

\section{Appendix. Descriptions and Examples of Innovation Provided to the Leaders}

\section{Innovation}

Innovation is an important product, process, or idea leading to a new or improved product that is new to the organization. According to this definition, new products developed, existing products improved, and custommade projects which display significantly different attributes from the firms' previous products are considered as product innovations in this study.

\section{Technological Product Innovation}

The term product is used to cover both goods and services. Technological product innovation can take two broad forms: A technologically new product is a product whose technological characteristics or intended uses differ significantly from those of previously produced products. Such innovations can involve radically new technologies, can be based on combining existing technologies in new uses, or can be derived from the use of new knowledge. A technologically improved product is an existing product whose performance has been significantly enhanced or upgraded. A simple product may be improved (in terms of better performance or lower cost) through the use of higher-performance components or materials, or a complex product that consists of a number of integrated subsystems may be improved by partial changes to one of the subsystems.

Examples of Technological Innovations in Software Development Companies

* The introduction of new multimedia software applications that can be used for educational purposes, thus eliminating the need for a real life human instructor.

* The development of a whole range of different customer packages in which clients are offered varying degrees of assistance/support. 


\section{Support Organizations}

TIDEB (Technology Monitoring and Evaluation Board), located within TUBITAK (Scientific and Technical Research Council of Turkey), provides subsidies and assistance to industrial and software development companies for their development and improvement projects. Financing is provided for several items such as personnel, equipment, software, publications, material, travel, and consulting services purchased. (This assistance is based on the Decree by Government published in June 1995 and improved in November 1998. The responsible agency is the Undersecreteriat of Foreign Trade).

TTGV (Technology Development Foundation of Turkey) is a nonprofit association whose mission is to distribute World Bank funds allocated by the Treasury to finance R\&D, and it assumes the credit risk involved. Similar to TIDEB, it provides support to industrial and software development companies for their development and improvement projects. It provides long-term subsidized loans to companies for their expenditures such as personnel, equipment, software, publications, material, travel, and consulting services purchased. 